\title{
PENGARUH PROFITABILITAS TERHADAP NILAI PERUSAHAAN DENGAN STRUKTUR MODAL SEBAGAI VARIABEL MODERASI PADA PERUSAHAAN MANUFAKTUR INDUSTRI BARANG KOMSUMSI SUB SEKTOR MAKANAN DAN MINUMAN TAHUN 2014 - 2017
}

\section{THE EFFECT OF PROFITABILITY TO FIRM'S VALUE WITH CAPITAL STRUCTURE AS MODERATING VARIABLE AT MANUFACTURING COMPANY INDUSTRY CONSUMER GOODS SUB SECTOR FOOD AND BEVERAGE 2014 - 2017}

\author{
Inge Lengga Sari Munthe \\ Fakultas Ekonomi Universitas Maritim Raja Ali Haji (Tanjungpinang) \\ Email : ingemunthe@yahoo.com
}

\begin{abstract}
ABSTRAK
Penelitian ini bertujuan untuk menganalisa pengaruh profitabilitas terhadap nilai perusahaan dengan struktur modal sebagai variabel moderasi di perusahaan sub sektor makanan dan minuman. Jumlah populasi ada 18 perusahaan. Metode pengambilan sampel dengan purposive sampling. Terdapat 11 sampel perusahaan. Metode penelitian dengan uji statistik dimana juga menggunakan uji analisis regresi moderasi. Hasillnya adalah secara simultan dan parsial profitabilitas dan struktur modal berpengaruh terhadap nilai perusahaan. Adjusted $\mathrm{R}^{2}$ bernilai $71,6 \%$. Hal ini berarti ada $28,4 \%$ lagi selain profitabilitas dan struktur modal yang mempengaruhi nilai perusahaan.Struktur modal juga dapat memperkuat pengaruh dari profitabilitas ke nilai perusahaan. Hal ini dapat dilihat dari beta Z yang bersifat positif dimana nilai perusahaan akan naik $9,8 \%$. Struktur modal juga merupakan quasi moderator yaitu pengaruh struktur modal terhadap nilai perusahaan dan pengaruh interaksi $Z$ terhadap nilai perusahaan juga signifikan.
\end{abstract}

Kata Kunci : Profitabilitas, Struktur Modal, Nilai Perusahaan, Variabel moderasi.

\begin{abstract}
This research aims to analyze the effect profitability to firm value with capital structure as moderating variable in sub sector food and beverage.There 18 companies as population. It uses purposive sampling to take sample. There are 11 companies as samples. Reseach method with statistic test where use moderating regression analysis. The results are profitability and capital structure have effect on firm value for simltaneously and partial respectively. Adjusted $R^{2}$ is $71,6 \%$. It means that there is $28,4 \%$ more beside profitability and capital structure can influence firm's value. Capital structure also strength the effect from profitability to company value. We can see from beta $Z$ that has positive value where firm's value will rise $9,8 \%$. Capital structure is a quasi moderating where as the effect of capital structure to firm's value and the effect of $Z$ interaction to firm's value is also significant.
\end{abstract}

Keywords : Profitability, Capital Structure, Company Value, Moderating Variable. 


\section{PENDAHULUAN}

Perusahaan makanan dan minuman adalah perusahaan yang bergerak dalam bidang menghasilkan makanan dan minuman untuk kemudian dijual di pasaran. Perusahaan ini termasuk perusahaan yang fast-moving. Pada tahun 2016, ada beberapa perusahaan yang menambah lagi jumlah saham yang beredar. Bila diamati, harga nominal saham juga semakin mengecil. Hal ini menyebabkan harga pasar dari jumlah saham yang beredar (market value of outstanding shares) melonjak dari 2015 ke 2016. Hal ini juga berimbas kepada nilai perusahaan. Berikut rata-rata dari nilai perusahaan dengan menggunakan Tobin's $Q$ dari sampel perusahaan.

Tabel 1 . Rata-Rata Nilai Perusahaan

\begin{tabular}{lcccc}
\hline Tahun & $\mathbf{2 0 1 4}$ & $\mathbf{2 0 1 5}$ & $\mathbf{2 0 1 6}$ & $\mathbf{2 0 1 7}$ \\
\hline Nilai perusahaan & 2,53 & 2,43 & 3,04 & 3,15 \\
\hline
\end{tabular}

Sumber : Data diolah

Profitabilitas dari perusahaan jenis ini juga mengalami penurunan. Tapi terjadi lonjakan yang cukup tinggi dari 2015 ke 2016. Walau kemudian pada tahun 2017 profitabilitas juga turun dengan cukup tajam. Sepertinya adanya penjualan yang jumlah berfluktuatif dari tahun $2014 \mathrm{sd}$ 2017. Berikut rata-rata ROA dari perusahaan sampel.

Tabel 2 . Rata-Rata ROA

\begin{tabular}{lllll}
\hline Tahun & $\mathbf{2 0 1 4}$ & $\mathbf{2 0 1 5}$ & $\mathbf{2 0 1 6}$ & $\mathbf{2 0 1 7}$ \\
\hline ROA & 12,04 & 10,94 & 13,75 & 9,64 \\
\hline
\end{tabular}

Sumber : data diolah

Tetapi untuk struktur modal, cenderung mengalami penurunan dari 2014 sd 2017. Hal ini bisa jadi karena tidak adanya penambahan utang, atau jumlah ekuitas yang cenderung meningkat. Berikut rata-rata DER dari perusahaan sampel.

Tabel 3 . Rata-Rata DER

\begin{tabular}{lcccc}
\hline Tahun & $\mathbf{2 0 1 4}$ & $\mathbf{2 0 1 5}$ & $\mathbf{2 0 1 6}$ & $\mathbf{2 0 1 7}$ \\
\hline DER & 1,16 & 1,03 & 0,90 & 0,75 \\
\hline
\end{tabular}

Berdasarkan uraian diatas,maka perumusan masalah adalah sebagai berikut : 1) Apakah profitabilitas dan struktur modal berpengaruh terhadap nilai perusahaan, secara parsial dan simultan; 2) Apakah Struktur modal dapat memoderasi hubungan profitabilitas terhadap nilai perusahaan.

\section{LANDASAN TEORI}

\section{Nilai Perusahaan}

Saham merupakan secarik kertas yang menunjukkan hak pemilik kertas tersebut untuk memperoleh bagian dari prospek atau kekayaan perusahaan yang menerbitkan saham tersebut dan berbagai kondisi untuk melaksanakan hak tersebut. Harga saham pada transaksi di pasar modal adalah harga saham yang berasal dari mekanisme pasar yakni permintaan dan 
penawaran pasar (Husnan dan Pudjiastuti,2006). Harga yang bersedia dibayar oleh calon pembeli diartikan sebagai harga pasar atas perusahaan itu sendiri. Di bursa saham, harga pasar berarti harga yang bersedia dibayar oleh investor untuk setiap lembar saham perusahaan. Oleh karenanya dapat dikatakan bahwa nilai perusahaan adalah merupakan persepsi investor terhadap perusahaan yang selalu dikaitkan dengan harga saham (Wasis, 1991). Saham biasa adalah instrumen ekuitas yang merupakan subordinat dari seluruh kelompok instrumen ekuitas lain. Saham biasa mungkin mempunyai lebih dari satu kelas saham (PSAK 56, 2016). Harga suatu saham dapat berfluktuasi secara cepat dalam hitungan waktu yang sangat cepat, sehingga investor ataupun pihak yang berkepentingan disarankan untuk sering melihat mengecek posisi harga saham perusahaan melalui fasilitas yang ada (Mahapsari dan Taman, 2013).

Salah satu dalam menghitung nilai pasar adalah dengan Tobin'sQ. Rasio ini menunjukkan estimasi pasar keuangan saat ini tentang nilai hasil pengembalian dari setiap dolar investasi. Tobin's $Q$ merupakan ukuran yang lebih teliti seberapa efektif manajemen memanfaatkan sumber-sumber daya ekonomis dalam kekuasaannya (Anggraini, 2017). Formulasinya adalah penjumlahan dari nilai pasar dari jumlah lembar saham yang beredar dengan total utang dan kemudian dibagi dengan total aset

\section{Struktur Modal}

Struktur modal adalah proporsi dalam pemenuhan kebutuhan belanja perusahaan dengan sumber pendanaan jangka panjang yang berasal dana internal dan eksternal. Struktur modal adalah kombinasi dari utang dan ekuitas dari struktur keuangan jangka panjang ( Husnan, 2004). Ada 2 alasan utama yang berhubungan dengan struktur modal, yaitu: perubahan struktur modal akan mempengaruhi biaya modal secara keseluruhan dan biaya modal ini akan digunakan sebagai cut of rate pada pengambilan keputusan investasi (Wasis, 1991). Struktur modal juga bisa mengalami perubahan karena adanya Struktur modal juga bisa mengalami perubahan karena adanya assymetric information antar pemegang saham dengan manajer perusahaan. Hal ini terjadi karena adanya informasi yang diketahui hanya manajer perusahaan, tapi tidak diketahui oleh pemegang saham (Brigham, Houston, 2011).

\section{Profitabilitas}

Rasio profitabilitas adalah rasio yang mengukur tingkat kesuksesan atau kegagalan dari perusahaan dalam suatu periode waktu tertentu (Kieso, Weygandt, 2014). Berikut rasio profitabilitas :

1. Return on Asset (ROA) adalah mengukur keuntungan dari total aset yang digunakan. ROA juga merupakan kombinasi dari efek margin laba dengan perputaran total aset. Menghitung ROA adalah dengan cara membagi laba bersih dengan rata-rata total aset.

2. Profit Margin on Sales adalah mengukur keuntungan dari penjualan bersih perusahaan.

3. Return on Equity (ROE) adalah mengukur keuntungan dari sudut pandang pemegang saham. ROE menunjukkan berapa laba yang dihasilkan dari modal yang ditanamkan oleh pemilik. ROE dapat membantu investor untuk melihat ketidakberhargaan dari saham bila pasar sedang tidak berjalan baik. Menghitung ROE adalah dengan cara selisih antara laba bersih dengan dividen preferen dan membaginya dengan rata-rata ekuitas.

4. Earning per share (EPS) adalah mengindikasikan laba yang dihasilkan dari setiap lembar saham biasa. Tidak untuk saham prioritas. Karena itu, EPS juga dilaporkan di dalam laporan 
laba rugi. Menghitung EPS adalah dengan cara selisih laba bersih dengan dividen preferen dan membaginya dengan rata-rata tertimbang dari saham.

5. Payout Ratio adalah ratio yang membandingkan dividen tunai yang dibayarkan ke pemegang saham dengan laba bersih.

Dalam penelitian ini, maka profitabilitas yang dipakai adalah ROA.

\section{Pengembangan Hipotesis}

Profitabilitas mencerminkan berapa laba yang dihasilkan oleh perusahaan. Laba yang tinggi mencerminkan kinerja yang baik dari perusahaan. Hal ini memberi informasi ke pasar, sehingga dapat mempengaruhi nilai perusahaan. Profitabilitas yang tinggi, membuat investor tertarik untuk membeli saham perusahaan. Sehingga hal ini dapat membuat nilai perusahaan naik.

Hipotesis 1 : Diduga ROA berpengaruh terhadap harga saham.

Penerbitan utang menimbulkan beban bunga di laporan laba rugi. Semakin tinggi beban bunga, maka akan semakin kecil laba perusahaan. Bila ada assymetric information, maka akan menimbulkan signal yang mempengaruhi nilai perusahaan.

Hipotesis 2 : Diduga struktur modal berpengaruh terhadap harga saham.

Struktur modal merupakan berhubungan dengan penerbitan utang jangka panjang. Dalam Trade-off theory, bila perusahaan menerbitkan utang, maka perlindungan pajak (tax shield) dan biaya agensi serta biaya kebangkrutan harus dipertimbangkan. Penerbitan utang mengakibatkan biaya agensi dan biaya kebangkrutan menjadi rendah. Tapi menimbulkan beban bunga dari utang. Hal ini mengakibatkan nilai perusahaan dimana salah satu faktornya adalah harga saham, akan naik. (Chen, 2011). Bila manajer berkeyakinan bahwa prospek usaha akan baik dengan berutang, maka manajer dapat berkomunikasi kepada investor. Manajer menggunakan utang, untuk membuat perusahaan lebih baik. Hal ini merupakan signal yang baik,sehingga dapat meningkatkan nilai perusahaan.

Hipotesis 3 : Diduga struktur modal dapat memoderasi hubungan antara ROA dengan nilai perusahaan.

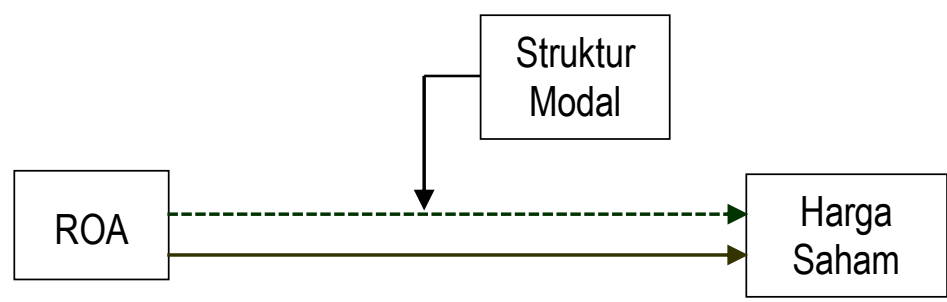

Gambar 1. Kerangka Pemikiran 


\section{METODOLOGI PENELITIAN}

\section{Jenis dan Sumber Data Penelitian}

Jenis data yang dipakai adalah data sekunder. Sumber data penelitian adalah berasal dari laporan keuangan yang telah dipublikasikan di Bursa Efek Indonesia yang ada idx.go.id, sesuai sampel. Populasi yang dipakai adalah perusahaan industri barang komsumsi sub sektor makanan dan minuman tahun 2014-2017. Pengambilan sampel adalah dengan purposive sampling. Jumlah populasi ada 18, dimana yang memenuhi kriteria hanya 11 perusahaan. Total data adalah $11 \times 4=44$ data.

\section{Metode Analisis dan Hipotesis}

Metode analisis data adalah dengan menggunakan uji statistik, dengan menggunakan SPSS v.20. Berikut tahapannya :

1. Uji Asumsi Klasik, meliputi uji normalitas dan uji linieritas.

2. Uji Hipotesis berupa : uji koefisien $\mathrm{R}^{2}$, uji parsial (uji t), uji simultan (uji F) dan analisis regresi moderasi.

Langkah analisis adalah sebagai berikut :

1. Uji regresi berganda dari $R O A\left(X_{1}\right)$ dan Struktur Modal $(Z)$ ke nilai perusahaan ( $Y$ ).

2. Uji regresi berganda dari $R O A\left(X_{1}\right)$, Struktur Modal ( $Z$ ) dan Struktur modal ${ }^{*} \operatorname{ROA}$ ( interaksi $Z{ }^{*} X_{1}$ ) ke harga saham $(Y)$.

\section{Operasionalisasi Variabel Penelitian}

Nilai Perusahaan $=\frac{(\text { MarketValueofOutstandingShares }+ \text { TotalDebt })}{\text { Total Aset }}$

$\mathrm{ROA}=\frac{\text { Net Income }}{\text { Average Total Aset }}$

Struktur modal proksinya adalah Debt to Equity Ratio ( DER ). Berikut rumusnya

DER $=\frac{\text { Toatal Debt }}{\text { Total Equity }}$

MVS $=$ HSP $x$ JSB

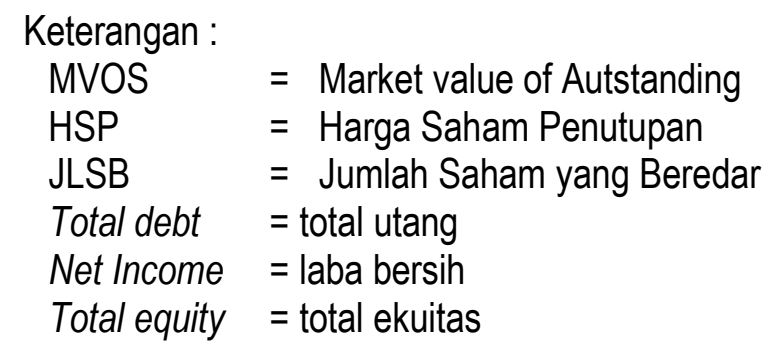


HASIL DAN PEMBAHASAN

Uji Statistik ROA dan DER terhadap Nilai Perusahaan (NP)

Tabel 4. Hasil Uji Statistik ROA dan DER terhadap Nilai Perusahaan

\begin{tabular}{|c|c|c|c|c|}
\hline \multicolumn{4}{|l|}{ Keterangan } & Nilai \\
\hline \multicolumn{4}{|l|}{ R Square } & 0,729 \\
\hline \multicolumn{4}{|c|}{ Adjusted R Square } & 0,716 \\
\hline \multicolumn{4}{|l|}{ F hitung } & 55,219 \\
\hline \multicolumn{4}{|l|}{ Probabilitas } & 0,000 \\
\hline Keterangan & $\begin{array}{c}\text { Unstandarized } \\
\text { Coefficients }\end{array}$ & $\begin{array}{l}\text { Standarized } \\
\text { Coefficients }\end{array}$ & Uji-T & $\begin{array}{l}\text { Probabilitas } \\
\text { (sig a } 0,05)\end{array}$ \\
\hline Constant & $-1,383$ & & $-2,692$ & 0,010 \\
\hline $\operatorname{ROA}\left(X_{1}\right)$ & 0,220 & 0,728 & 8,762 & 0,000 \\
\hline $\operatorname{DER}\left(\mathrm{Y}_{2}\right)$ & 1,645 & 0,320 & 3,848 & 0,000 \\
\hline
\end{tabular}

Dependent Variable: NP $\left(\mathrm{Y}_{1}\right)$ data diolah SPSS v.20

1. Secara simultan, ROA dan DER berpengaruh terhadap Nilai Perusahaan. Hal ini dapat dilihat dari probabilitas dimana nilainya $0,000<0,05$. Adjusted $R^{2}$ bernilai $71,6 \%$. Hal ini berarti ada $28,4 \%$ lagi selain ROA dan DER yang mempengaruhi NP.

2. ROA berpengaruh terhadap NP secara parsial. Hal ini dapat dilihat dari probabilitas $0,000<0,05$. ROA berpengaruh positif 0,220 , artinya bila ROA naik $1 \%$, maka nilai perusahaan akan naik sebesar $22 \%$.

3. DER berpengaruh terhadap NP secara parsial. Hal ini dapat dilihat dari probabilitas $0,000<0,05$. DER berpengaruh positif 1,645 , artinya bila DER naik $1 \%$, maka nilai perusahaan akan naik sebesar 1,645 kali.

Tabel 5. Uji ROA dan DER ROA terhadap Nilai Perusahaan

\begin{tabular}{|c|c|c|c|c|}
\hline \multicolumn{4}{|l|}{ Keterangan } & Nilai \\
\hline \multicolumn{4}{|l|}{ R Square } & 0,820 \\
\hline \multicolumn{4}{|c|}{ Adjusted R Square } & 0,811 \\
\hline \multicolumn{4}{|l|}{ F hitung } & 65,672 \\
\hline \multicolumn{4}{|l|}{ Probabilitas } & 0,000 \\
\hline Keterangan & $\begin{array}{c}\text { Unstandarized } \\
\text { Coefficients }\end{array}$ & $\begin{array}{l}\text { Standarized } \\
\text { Coefficients }\end{array}$ & Uji-T & $\begin{array}{l}\text { Probabilitas } \\
\text { (sig a 0,05) }\end{array}$ \\
\hline Constant & $-1,383$ & & $-2,692$ & 0,010 \\
\hline $\mathrm{ROA}\left(\mathrm{X}_{1}\right)$ & 0,075 & 0,246 & 2,301 & 0,027 \\
\hline DER * ROA (Z) & 0,098 & 0,699 & 6,542 & 0,000 \\
\hline
\end{tabular}

Dependent Variable: NP $\left(\mathrm{Y}_{1}\right)$ data diolah SPSS v.20

1. Secara simultan, ROA dan $D E R{ }^{*} R O A$ berpengaruh terhadap Nilai Perusahaan. Hal ini dapat dilihat dari probabilitas dimana nilainya $0,000<0,05$. Adjusted $R^{2}$ bernilai $81,1 \%$. Hal ini berarti ada 10,9\% lagi selain ROA dan DER * ROA yang mempengaruhi NP. 
2. ROA berpengaruh terhadap NP secara parsial. Hal ini dapat dilihat dari probabilitas $0,027<0,05$. ROA berpengaruh positif $0,0,075$, artinya bila ROA naik $1 \%$, maka nilai perusahaan akan naik sebesar $7,5 \%$.

3. Dilihat dari beta dan signifikansi, maka moderasi dari DER memperkuat pengaruh dari ROA ke nilai perusahaan. Hal ini dapat dilihat dari beta DER * ROA yang bersifat positif yaitu 0,098 . Pengaruh memperkuat ini juga signifikan bila dilihat dari signifikansinya dibawah 0,05 .

4. DER juga merupakan quasi moderator yaitu pengaruh DER terhadap nilai perusahaan dan pengaruh interaksi DER * ROA terhadap nilai perusahaan juga signifikan.

\section{Pembahasan}

1. ROA berpengaruh positif terhadap nilai perusahaan. Hal ini menunjukkan bahwa manajemen perusahaan bersifat efisien dalam mengelola perusahaan sehingga menghasilkan nilai perusahaan yang tinggi juga. Dari beberapa sampel perusahaan, terdapat penambahan dari jumlah saham yang beredar. Sehingga bila dihitung market value of outstanding shares, maka akan menghasilkan nilai perusahaan yang besar.

2. DER berpengaruh positif terhadap nilai perusahaan. Hal ini karena dari sampel didapatkan bahwa nilai DER cenderung turun dari 2014 sd 2017. Sementara itu harga saham juga berfluktuatif naik turun. Mempunyai utang berarti menambah aset. Sehingga dengan market value of outstanding shares dan ditambah utang dan dibagi total aset yang besar, maka DER bergerak searah dengan nilai perusahaan.

3. Struktur modal dapat memoderasi hubungan antara ROA dengan nilai perusahaan. DER memperkuat hubungan antara ROA dengan nilai perusahaan. Utang menimbulkan beban bunga. Beban bunga mempengaruhi laba atau rugi perusahaan. Bila dilihat dari sampel, DER cenderung turun. Hal ini juga membuat beban bunga dibayar turun. Karena itu, maka laba juga cenderung meningkat. Selain itu juga, ekuitas juga cenderung bertambah, disebabkan adanya penambahan jumlah saham yang beredar, yang diikuti juga dengan pengurangan harga nominal saham.

\section{REKOMENDASI DAN KEBIJAKAN}

\section{Rekomendasi}

Berdasarkan hasil penelitian ini, maka sesuai dengan perumusan masalah maka :

1. Profitabilitas berpengaruh positif 0,220 , artinya bila profitabilitas naik $1 \%$, maka nilai perusahaan akan naik sebesar $22 \%$. Struktur modal berpengaruh positif 1,645 , artinya bila struktur modal naik 1\%, maka nilai perusahaan akan naik sebesar 1,645 kali. Secara simultan, profitabilitas dan struktur modal berpengaruh terhadap nilai perusahaan.

2. Moderasi dari struktur modal memperkuat pengaruh profitabilitas ke nilai perusahaan. Hal ini dapat dilihat dari beta $Z$ yang bersifat positif dimana nilai perusahaan akan naik $9,8 \%$. Struktur modal juga merupakan quasi moderator yaitu pengaruh struktur modal terhadap nilai perusahaan dan pengaruh interaksi $Z$ terhadap nilai perusahaan juga signifikan. 


\section{Kebijakan}

1. Bila dilihat dari adjusted $r$ square, maka variable lain bisa ditambahkan yang dapat mempengaruhi nilai perusahaan.

2. Selain itu, variabel lain juga bisa dicari sebagai variabel moderasi.

\section{DAFTAR PUSTAKA}

Anggraini. 2017. Pengaruh Profitabilitas terhadap Nilai Perusahaan dengan Struktur Modal sebagai Variabel Moderasi. Skripsi. Universitas Islam Negeri Maulana Malik Ibrahim. Malang.

Brigham, et.al. Manajemen Keuangan. 2011.Erlangga. Jakarta.

Husnan, Suad. 2004. Dasar-Dasar Teori Portfolio dan Analisis Sekuritas, UPP Amp YKPN; Yogyakarta.

Husnan,et.al. 2006. Dasar-Dasar Manajemen Keuangan. Edisi Kelima. Yogyakarta : UPP STIM YKPN.

Kieso D.E., et.al, 2014, Intermediate Accounting 2014 FASB Update, 15th edition, USA, Wiley \&Sons.

Li-Ju Chen and Shun-Yu Chen. 2011. The influence of profitability on firm value with capital structure as the mediator and firm size and industry as moderators. Investment Managemeng and Financial Innovations. LLC "Consulting Publishing Company "Business Perspectives".

Mahapsari, et.al. 2013. Pengaruh Profitabilitas, Struktur Aktiva, dan Pertumbuhan Penjualan terhadap Harga Saham dengan Struktur Modal Sebagai Variabel Intervening Pada Perusahaan Manufaktur. Jurnal Nominal. Volume 2, nomor 1. Universitas Negeri Yogyakarta.

PSAK 56,Standar Akuntansi Keuangan. 2016. Ikatan Akuntan Indonesia.

Vona, et.al. 2016. Pengaruh Profitabilitas, Aset Tetap dan Pertumbuhan Penjualan terhadap financial leverage serta dampaknya terhadap harga saham pada perusahaan yang terdaftar di Bursa Efek Indonesia. Jurnal Magister Akuntansi Pasca Sarjana Universitas Syah Kuala. ISSN 2302-0164.Volume 5, no.1 Februari 2016.

Wasis, 1991. Manajemen Keuangan Perusahaan. Edisi Kedua. Setia Wacana. Semarang. www.idx.go.id 